\title{
Laughing About Caste
}

\section{An analysis of how caste considerations find representation in the genre of English stand- up comedy on the internet in India}

\author{
Shreyashi Ganguly ${ }^{1}$ \\ ${ }^{1}$ Department of Sociology, University of Victoria, British Columbia, Canada \\ E-mail: shreyashig@uvic.ca
}

\begin{abstract}
The literature on humour in India has largely evaded the question of how humour intersects with caste stratification. Not much has been written about humour's potential to discriminate against certain caste groups of the lower social order. Similarly, the traditional media in India has been silent about the issue of caste following which, social media has emerged as the 'counter publics' where caste identity can be collectively and freely expressed. Taking the now flourishing brand of English stand-up comedy on the Internet in India as an entry point, this study investigates if the symbolic articulation of caste identities is at all made possible in this genre. Using a combination of discourse analysis and social media analysis, to examine the jokes produced in stand-up shows, in this paper I try to gauge how frequently, and in what ways, caste finds mention in these performances on the Internet. I find that caste identity, and the associated discrimination, are hardly evoked in the comedians' discourse. And when spoken about, they are often done so in a disparaging light. I conclude this paper by illuminating the ways in which this disparaging humour bolsters caste discrimination, sustains stereotypes and, in the process, conditions the normalized exclusion of lower-caste groupings from the public sphere.
\end{abstract}

Keywords: Caste, stand-up comedy, Dalit, Internet, counter-public, post-caste, disparagement humour

\section{Introduction: A Brief History of Humour Studies in India}

India has a historically rich comic tradition, the earliest instances of which have been recorded in Bharata's Natyashastra, the ancient treatise on the theory of drama (Kumar 82). Bharata classifies humour as one of the eight mood effects that can be created through drama. This classification of humour as a theatrical trope has provided it a foundation on which to flourish in public and political spaces in contemporary times (Kumar 82). C.M. Naim writes about the $16^{\text {th }}$ century Mughal emperor, Akbar, and the verbal duels replete with wit and satire that ensued between him and his court advisor, Birbal, which have lingered on in the popular public imagination (1456). Satire as a form of political humour, in fact, has had a robust legacy in the subcontinent since at least the days of the consolidation of the British empire. The raja, the nawab, the daroga, the jotedar, have often been the target of sharp jokes and caricatures (Joshi). The newspapers that emerged during this time were directed at resisting colonial rule and would often carry political satire pieces aimed at destabilizing the Empire (Kumar 83). They often published political cartoons that have been an important tool for resistance movements (Khanduri 463). In the genre of entertainment, too, comedy has been an important motif. The Hindi film industry, more popularly known as Bollywood, has immortalized actors such as Mehmood, Johnnie Walker and Johhny Lever, known for their impeccable comic timing (Nüske 14). In contemporary times, considerable attention has been devoted to the tradition of stand-up comedy in India and its newly burgeoning English variant that has gained popularity with the advent of the Internet and the various social media platforms (Nüske 14, Sahoo 241, Paul 121, Kay 4).

Religion, particularly, has been an important theme where literature on humour in India is concerned. Lee Seigel 
in his book, Laughing Matters: Comic tradition in India, chronicles the way humour has been described and understood in the ancient Indian religious texts (xv). Koenraad Elst has shown that in the history of Hinduism the predominant religion in the country with the majority of the population practising it — humour is not a counter current against the orthodoxy but is quite common and open (35). Edwin Gerow has explicated how humour manifests in religious rituals, familial relationships throughout the ages in the country (146). Humour, Wit, and Satire from Indian Classics presented numerous satiric and parodic anecdotes from ancient texts within Hinduism, Jainism, and Buddhism (Thomas 2). But these studies rarely acknowledge how the use of humour has negatively impacted religious or, for that matter, any other minority groups in the country (Weaver 487). Thus, whereas studies from across the world have devoted considerable attention to how visible minorities Jews, People of Colour, women, and alternate sexualities are often at the receiving end of jokes (Davies 4), the studies on humour in India mainly limit themselves to chronicling the historical trajectory through which humour has progressed. There, therefore, exists a considerable knowledge gap as to how humour aligns with the different axes of social stratification to discriminate against groups perched at disadvantageous positions. Take for instance, the question of caste stratification. Elst, in his essay on humour in Hinduism does talk about jokes on the stereotype of the Brahmin: the caste of the highest social order. But he also mentions that these jokes were possible only because they were written by Brahmins themselves and thus served the function of self-deprecating humour (39). Very few works have actually looked into the way caste hierarchy, discrimination can be themes in the discourse on humour (Waghmore 160, Sahoo 241). Given how important caste is to an understanding of Indian society, the sparse literature on the topic is surprising, to say the least. Waghmore argues that this can be understood as a manifestation of the unwillingness to broach the issue of caste altogether, an unwillingness that pervades much of the public discourse in the country (155).

This paper is thus an attempt to unpack the ways in which humour facilitates caste discrimination in the contemporary Indian public discourse. By examining representations of caste inequality in comedy, the study throws open an avenue through which humour in contemporary India can be analysed. But more important, it intends to start a new discussion on caste.

\section{Caste in Contemporary Indian Public Discourse}

Caste continues to be a pervasive feature of the Indian public discourse. But despite being the subject of extensive scholarship and scrutiny, it remains difficult to arrive at a comprehensive theoretical formulation of what exactly this mode of stratification entails due to its varying nature and composition across the country. Simply understood, an individual's caste ascription determines their life chances, starting from their food habits, chances of obtaining an education, employment opportunities, their choice of partners and even the treatment they receive at death. It has the rare status of being an identity, a social system and the basis of discrimination, all at once (Mosse 4). It is so ingrained in society that it is difficult - if not impossible — to imagine a life without it. Dr Bhimrao Ramji Ambedkar, is the social reformer and political jurist who was one of the first to have led the movement against social discrimination against the lower castes and the practice of untouchability, and is considered the founding father of the modern anti-caste movement. Ambedkar argues that the problem of caste is

a vast one both theoretically and practically. Practically, it is an institution that portends tremendous consequences. It is a local problem, but one capable of much wider mischief, for as long as caste in India does exist, Hindus will hardly intermarry or have any social intercourse with outsiders; and if Hindus migrate to other regions on earth, Indian caste would become a world problem. (132)

Surely enough, a recent study has shown that the Indian diaspora is, in fact, an ardent propagator of caste discrimination (Ray).

The caste system may be defined as a hierarchy of endogamous divisions in which membership is hereditary and permanent (Berreman 120). In other words, an individual born into a caste has no way of escaping the identity that their ascription awards, unless, very rarely, in the case of women, by marriage. Ambedkar argues that endogamy is a defining feature of the caste hierarchy and that the strict observance of this custom and social superiority by the Brahmins sufficiently proves that it was this group that founded and contributes to the maintenance of the institution of caste (Ambedkar 133). Across the northern belt of the country, the caste system follows the varna (colour) pattern closely that serves to classify the castes as Brahmins, Kshatriyas, Vaishyas, Shudras and the untouchables (Jaffrelot 757), thus establishing that caste divisions also imbue a racial connotation. Another distinct feature of the caste system are the notions of purity and pollution (Gupta 410). Louis Dumont, the most influential proponent of this theory described the caste hierarchy as one that essentially serves to separate the pure from the impure. On one end of the spectrum stand the Brahmins - the twice borns: the caste that is most pure, while on the other end, and in direct 
opposition to them, stand the untouchables or the caste of the lowest order. All other castes lie in between (Gupta 411). The untouchables are now known as the Dalits, a term popularized by Ambedkar, the literal translation of which means the broken or the downtrodden (Sharma 843). In the scheme of purity versus pollution, commingling among the castes is strictly prohibited (Gupta 411), so much so that even today, Dalit encampments are usually located at the fringes of the village in order to minimize their contact with castes higher than them (Desai and Kulkarni). Not too long ago, Dalits had to announce their arrival in a village by beating drums so that the other castes would not have to encounter even their shadows (Jaffrelot 758). An excluded section of the society, Dalits are often subject to enforced landlessness and servitude and relegated with the most menial tasks such as manual scavenging and disposing of the dead (Mosse 9).

Historically speaking, the caste system underwent significant changes during colonial times. With the introduction of the Census, the caste divisions were recorded in great details that gave the lower castes a basis on which to organize their agenda and political demands. The British policy of compensatory discrimination based on the reservation of seats in the bureaucracy and in the assemblies contributed to the crystallization of new social categories that resented their non-representation (Jaffrelot 757). AntiBrahmin sentiments started being conveyed vocally during these times, and the British also enacted laws that served to bring down the burden of untouchability (Gupta 413). The process of challenging the established hierarchies was, thus, well underway. With the independence of India in 1947, the politics of caste assumed a different character. The Constitution of India, pioneered by Ambedkar, not only abolished untouchability but also reserved jobs and seats in government jobs and educational institutions for the lower castes and the indigenous tribes (Gupta 412). Reservation schemes have since then been attacked by privileged groups everywhere as the denial of the merit of 'deserving' another word for 'upper-caste' — candidates (Akbar). In the 1980s, the Mandal Commission took the agenda of castebased reservations a step further by also reserving seats for the Other Backward Classes, a group of castes identified as suffering from social, economic and political backwardness (Gupta 414). The implementation of the suggestions of the Mandal Commission created a nationwide furore, resulting in innumerable incidents of violence led mainly by members of the higher castes. The recommendations were criticized for not being a means to eliminate caste and its associated discrimination but instead a way to make this ascriptive marker a source from which to derive political clout (Gupta 414).
The caste system is constantly undergoing modifications. Harold Gould is of the opinion that in the rural areas, caste has come to be recognized as occupationally and hierarchically specialized endogamous social strata whereas in the urban context, it has arranged itself as interest groups sustained through endogamy and legitimized by religion (427). The question of class is inextricably tied to the notion of caste in ways that give rise to divisions and hierarchy within each of the caste divisions and make it difficult to understand them as homogenous entities. Better life chances mean that the upper castes have been able to acquire social and cultural capital that has placed them at a position of advantage, something that continues to elude the lower castes, who, by default, have been relegated to the margins of the society. But even then, it is fallacious to consider the Dalit category as a neatly packaged category where everyone that belongs to it has had a uniform experience. Even within this category, class connotations have ensured the prevalence of hierarchical divisions. But even though there is a considerable collusion between class and caste status, it can safely be said that the boundaries between the castes exist and the rituals and customs that serve to separate one caste from another are strictly maintained.

Caste, today, is decried as a social evil but it cannot be denied that it is an intrinsic feature of Indian social life; and so is caste-based discrimination. While Dalits have always been at the receiving end of violence from the upper castes, it is with the advent of the Narendra Modi-led Bharatiya Janata Party government in 2014, that incidents of caste-based violence have increased manifold all over the country. Reports suggest that violence against Dalits in the western state of Gujarat alone has seen a 35 per cent surge since 2014 (Smitha). Not to mention the many incidents that are forced to remain unreported. In 2018, a Dalit man was killed by the upper castes in his village in Gujarat because he grew a moustache: an indicator of upper caste status (Das). In Tamil Nadu, a Dalit man was assaulted by three caste Hindus and forced to eat human excreta (Vasudevan). A 14year-old Dalit girl was beheaded by an upper-caste man whose wife said he hated the girl specifically because of her caste (Gettleman and Raj). Even in urban areas, the predominance of caste remains undeterred. A recent web series on Netflix, Indian Matchmaking, lays bare the importance of caste in upper-class millennial matrimonial alliances. The practice of keeping separate utensils for the domestic help - most of whom usually hail from the lower castes - is widespread, implying that untouchability, in some form or the other, still continues to be an important motif of modern Indian social life.

However, the rising cases of caste-based discriminatory practices is complemented by a belief that 
caste is no longer an important social determinant in public discourse. Endorsed by the public institutions and mainstream media, the assumption is that caste identity no longer matters in the urban context. Outside academia, it is considered regressive to use caste as a lens to examine India (Akbar). Most incidents of violence involving lower castes are met with silence from higher authorities, and given the short-lived nature of public memory, the cases and the uproar are promptly forgotten. Numerous terms have been invented to refer to caste without explicitly mentioning it. Some of them include 'community' and 'family background' (Akbar). These terms, however, carry the full range of meaning that caste categories do. What this post-caste assumption essentially does is debilitate the fight for social justice and rights of the Dalit identity. The upper castes with their array of privilege compete for the same resources as the lower castes all the while criticizing the affirmative action policies.

\section{The Post-Caste Assumption in Indian Media: The Space for a Counter-Public Sphere}

Media organizations make news of even the most trivial matters but concerns such as manual scavenging, people refusing to cook for Dalit children in schools, or Dalits being displaced owing to urbanization, hardly hit the headlines (Rani). This makes apparent the aversion the traditional media harbours towards the discussion - any discussion - on caste. A reason behind this could be that a significant portion of the Indian broadcast media is owned by business houses, members of which hail from the upper castes. There is not a single adivasi or Dalit journalist among some 300 identified 'decision-makers' in the media (Nagarajan). For the elite sections of society, caste is not a part of their everyday lived reality and therefore, by extension, is not a reality at all. Adding to this is the fact that Dalits are often portrayed negatively in the media. Often highlighted as 'nuisance value', their demands, positive qualities and backgrounds are neglected to sustain their stereotypical images (Kumar).

It is this post-caste attitude of the traditional media that has pushed more and more Dalits to pursue social media as a space where open discussions on caste are made possible. Today, a plethora of forums that focus on the concerns of the Dalit community are available on the Internet. While some such as Round Table India conduct online, anti-caste debate, others such as Dalit Camera film debate, interview and upload them to YouTube (Dhillon). This has been facilitated by the rapid dissemination of the Internet in even remote areas (Chadha and Harlow 685). Now, people anywhere with access to Internet can exchange political messages with each other. Even in the face of political crackdowns on free speech and attempts to censor, cyberspace allows for political communication. Scholars have stressed social media's potential to open up space for marginalized communities and to award them social and political accountability (Kumar and Subramani 126, Thakur 361). Social media in India, therefore, has emerged as what is called the 'counter-publics' where instead of one exclusive sphere, there exists multiple counter public spheres where subaltern identities can be articulated effectively (Chadha and Harlow 673). By expressing outrage online, collectives can influence even the mainstream media (Chadha and Harlow 675). Online networking has brought social and cultural capital for the Dalit community, enabling millennial Dalits to employ social media for political purposes. Common online users in the Dalit community are becoming primary interpreters and agenda builders for the political claims on social networking sites, no longer depending heavily on non-Dalit leaders and the intelligentsia to represent claims to justice and equality (Thakur 361).

In 2016, Rohith Vemula, a Dalit PhD research scholar at the University of Hyderabad in the southern state of Telangana, committed suicide due to caste-based prejudices and practices at the institutional level (Farooq). Following his death, there was a massive furore on various social media platforms with the hashtag \#Dalitlivesmatter trending on Twitter (Thakur 365). Online activism and digital rage were successfully able to bring the issue into mainstream political debate and Vemula's suicide and the successive debate on discrimination in liberal institutions marked a watershed moment in the history of Dalit activism.

However, it remains a fact that most people belonging to the lowest rungs of the caste order do not have access to the basics of survival. For them, access to Internet and forums for public discussion remain a gilded dream. In most cases, therefore, it is the middle-class, educated Dalit voice that is most loudly heard on these counter-public spheres. But even then, the online media platforms are providing spaces for articulating alternative opinions, becoming a means for the subaltern identity to express lived experiences of systemic injustice and thereby, contributing to effective meaning-making practices (Thakur 371).

\section{Stand-Up Comedy in India: A Brief Introduction}

The power of the Internet to make a clip go viral is a modern-day cultural phenomenon (Kay 2). While this has changed the way activism is conceived, it has also significantly altered patterns of media consumption in India. With the social media boom, the comedy entertainment industry has also seen a simultaneous upsurge. Comedy shows in the form of situation comedies (Taarak Mehta ka Ooltah Chasmah), sketch comedies (The Great Indian Laughter show), political satire on news channels (The Week That Wasn't, Gustaakhi Maaf) and stand-up comedy 
competitions (The Great Indian Laughter Challenge) have always been popular on Indian television. But the widespread dissemination of the Internet, coupled with trends of globalization, has facilitated the emergence and steady growth of a brand of English stand-up comedy. This new variant is different from its already existing counterparts in the sense that it is mostly performed in front of a live audience and the clips are later circulated on the various social media platforms. Even though it is largely called English stand-up comedy, most of the performers juxtapose English with regional languages, but mainly Hindi, a technical apparatus known as 'linguistic code switching' to maximize laughter and stay relatable (Paul 124).

Stand-up comedy, in general, can be defined as "the oldest, basic, and deeply significant form of humorous expression" (Mintz 71). Oliver Double defined stand-up as an act which "usually involves a solo performer speaking directly to an audience, with the intention of provoking laughter, within the context of formalised entertainment, but it is an entity in itself, and is not contained within a larger narrative structure" (MacDonald 15). Stand-up comedy involves interaction between the audience and the performer (Sohail and Hasan). But in the case of the new brand of stand-up comedy in India, the clips are also circulated on the different social media platforms. The comments section underneath the videos, over and above the live audience, facilitates interaction and enables people to engage with the cultural texts in their own way.

The origins of English stand-up comedy in India as it is popular today can be traced back to the Internet boom in the early 2000s which made Western comedic content available to the Indian audience. The social media savvy population were slowly getting acquainted with comedians such as Vir Das and Russell Peters, who performed mostly in English (Paul 122). Gradually, in metropolitan cities such as Mumbai and Delhi which had an established pub culture, the American style stand-up comedy became a routine form of entertainment to provide the patrons novelty. And since most of them had returned home following the recession in the United States, a hint of nostalgia (Paul 122). Soon after, comedy clubs began opening up in different cities dedicated solely to showcasing comedic talent. Meanwhile, on YouTube, groups such as All India Bakchod (AIB), East India Comedy (EIC), The Viral Fever (TVF) came together to incorporate sketches and stand-up routines in their content (Paul 123). English stand-up comedy today is an entire industry complete with corporate collaborations, brand endorsements and huge annual turnovers. Many of the overthe-top (OTT) platforms such as Amazon Prime and Netflix have capitalized on the comedy boom and have programmed hour-long specials featuring some of the top comedians. Rohan Joshi, a comedian, and a member of the now dissolved comedy collective AIB, is of the opinion that the current comedy scene would not have worked a decade ago when social media was not there (Gopalakrishnan). In its formative years, Twitter was instrumental in publicizing live shows. Comic Zakir Khan also believes that the Internet has made it possible for stand-up to come to the same level as Bollywood or cricket in India (Gopalakrishnan). English stand-up comedy in India is still at a nascent stage which contributes to the fact that it largely remains undertheorized. But the publicity it has already garnered makes it an important lens through which to examine Indian social life.

Historically, stand-up comedy has been an important means of resistance, a tool for affecting change. The space it creates aims to challenge the dominant norms and upset the formal public discourse (Sahoo 241). Perez argues that stand-up comedy often breaches the norms of etiquette and repeatedly points out the significance of confronting touchy subjects and issues that do not always find expression in politically repressed societies. Stand-up comedy can be used to articulate alternate opinions and bring in the required consciousness to contest the dominant ideology (Sahoo 241).

English stand-up comedy in India, true to its form, is being heralded as a harbinger of change. It has made possible the articulation of opinions and topics that could not be explored on television with its strict laws of censorship. This content disguises itself as jokes and challenges the hegemonic narrative by unravelling the mask of authority (Paul 125). Furthermore, the fact that the content very often goes viral signals the popularity of YouTube and other similar social media platforms as counter public spheres capable of producing rational discourse on pertinent issues. This genre of comedy has brought sarcasm, vulgarity, dark humour into public consciousness and normalized them in the public comedic vocabulary. The comedians are being lauded for going off the beaten track, for speaking the unspeakable. Comedian Daniel Fernandes, who performs mostly in English, has a powerful set on YouTube titled "Marital Rape" (2015), in which he picks apart the societal negligence and the regressive attitude towards marital rape. He says, "I think marital rape is worse [than non-marital rape], because not only are you sexually violated but you have to wake up next morning and make your rapist a sandwich" (Fernandes). Such a discussion is practically unheard of in mainstream media and the laughter that ensues, possibly unimagined. In November 2016, the Narendra Modi government discontinued the five-hundred and thousandrupee notes, a move that threw the entire country in a mayhem. Weeks after the change, the ATMs still had long queues of people waiting to withdraw money. Comedian Varun Grover says in Hindi, "I met an uncle who was carrying a chair, I asked him why and he said he'll use the 
chair to sit outside the ATM" (Grover). Kunal Kamra, known best for his sharp critique of the BJP-led government and his many trysts with the police, does not shy away from ridiculing the jingoistic fervour of the government. Female comedians, specifically, have been commended for hitting out at the patriarchal nature of the society with their gigs on menstruation, body shaming and societal expectations topics otherwise considered taboo in public discussion. Aditi Mittal in a video on YouTube titled, "Sanitary Napkins | Things they wouldn't let me say" (2016), jokes "I have realized that saying the words sanitary napkin in public is like standing in a Hogwarts common room and saying the word "Voldemort"' (Mittal). Through their content, these comedians have been, to some extent, able to capture and confront the attitudinal changes India is going through.

But comedy is not without consequences. Ever since it gained traction in India, English stand-up comedy has been subject to much criticism and negative publicity. Comedians have received death threats, police complaints have been launched against them - the complaint against AIB after the roast routine they organized in 2015 continues to be an important event in the history of English stand-up comedy in India - and some such as Kamra have even been evicted because of the topics they evoke on stage (Singh). Religion and the government are particularly taboo topics when it comes to stand-up comedy, even though comedians continue to incorporate them in their content in some way. The documentary "I am Offended" (2015), aptly captures the nation's obsession with getting hurt over comedy content, but especially anything related to religion. In its most recent manifestation, the culture of offence-taking was in the headlines when a female comedian, Agrima Joshua, allegedly poked fun at Chhatrapati Shivaji Maharaj, a warrior venerated in the western state of Maharashtra. She was given rape threats in graphic details and even after she deleted the video and published a public apology, the trolling did not cease (Yadav).

In the last few years, the debate around political correctness (PC) has gained traction in India and in many ways, is said to be stifling comedy. But then comedy is, almost always, inextricably tied to the issue of PC. Kapil Sharma, one of the most popular comedians on television says, "My shows are watched by little children and grandmothers. They have faith that I will not say anything offensive... We have so many religions, languages, and caste groups in India that we grow up with a self-censorship device inside us" (Lakshmi). The Indian populace is still warming up to the idea of a person talking about a particular topic on stage, hence, the possibility of getting offended is quite high. Kenny Sebastian, in his video on YouTube, "Why I Don't Do Jokes About Politics in India" (2018), explains why he shies away from political topics. He is afraid that
Internet trolls will burn his family. "I do not want them to be crispy," he jokes (Sebastian). In fact, the culture of offencetaking in India has taken off almost immediately with the growth of the Internet. Incidentally, the same comments section that allows individuals to engage with the comedy becomes a hotbed of expletives and disparagement. Facilitating this is the garb of anonymity. In spite of these complexities, English stand-up in the country is constantly pushing the limits of free speech, testing the limits of what is acceptable. Comedians are constantly negotiating boundaries, failing multiple times at it but nevertheless setting new grounds for public dissemination of ideas. Given how pertinent this mode of comedy is in the public discourse, it is appropriate that it serves as a lens to examine how caste and comedy impinge upon each other in India today.

This study thus aims to understand if the silence around caste, that is a feature of mainstream media, also extends to the domain of English stand-up comedy on the Internet; if comedians talk about caste in the form of ascriptions, prejudice, and if the innumerable incidents of caste-based violence taking place all over the country ever find their way into any of the content. But most importantly, this paper looks at the identities of the comedians in order to gauge if this comedy space allows for the Dalit voice to be heard.

\section{Methodology}

Some claim that language simply reflects existing attitudes. Others maintain that language is a powerful weapon that can help to form or change attitudes. Examining language can then help explain why people laugh (Ross 2). The precise manner in which comedians employ language to evoke laughter is pivotal to my research and thus it was a conscious decision to use discourse analysis methodology for the purposes of the study. Starks and Trinidad are of the opinion that discourse analysis is concerned with how individuals use language to accomplish personal, social, and political aims and position themselves in relation to others. It is through mutual exchange that meaning is attributed to language and identities are negotiated and discourse analysis deals in the study of this (1374). However, this paper uses discourse analysis methodology in conjunction with a qualitative content analysis approach. The motive was to unpack the meanings that comedians attach to their jokes and arrange the findings into themes, and since a qualitative content analysis approach proposes to do just that, it was the best way to go about this study.

It is evident that this study deals largely with a social media analysis. The social media platforms have been treated as complex formations that shape ideas and worldviews of those consuming them (Caliandro 554). 
Borrowing from Christine Hine, these sites are understood to be both culture as well as cultural artefacts (Caliandro 554). This means that the social media platforms present a space where the comedians reproduce existing cultures, inequalities through their gigs.

\section{$\underline{\text { Methods of data collection and analysis }}$}

A multi-sited, mobile online ethnography of mainstream comedy videos was conducted. In other words, the comedians were followed across YouTube, Facebook, Twitter and any paid streaming websites where they might have put up content. By mainstream, I intend to convey that comedians who perform in only Hindi and English, the two most used languages in the comedy circuit, have been included in the study. Mainstream also means comedians whose content is available easily on YouTube thus ensuring that they are able to reach a wider gamut of audience. Even though there is a vibrant regional stand-up comedy scene in many parts of the country, most of these performances do not make it to social media platforms. Adding to it is the fact that regional comedy predominantly makes use of languages other than the two most widely used, making it inaccessible to audiences from other regions of the country. With the stand-up industry in India slowly finding its feet, there are many performers on the comedy circuit. But in order to limit the scope of the study, only those with the most number of subscribers on their YouTube channel were selected. The subscriber count illustrates how many have found the content relatable enough to follow the comedian. Keeping these considerations in mind, a sample of 15 comedians was drawn up. The website indianstandups.com which has a comprehensive list of all the comedians performing in India at a given point in time, was instrumental in this process. The number of subscribers was cross-checked from the comedians' individual YouTube channels. Some of these comedians tour internationally but this study includes only those performances which have been performed in front of a live audience in India. And even though the Internet awards a relative degree of permanency in terms of shelf life of the video clips, only the clips produced in or since 2017 have been examined. The list of comedians and their subscriber base on YouTube (as of April 30, 2019) are as follows:

- Zakir Khan (3.8 million)

- Kenny Sebastian (1.6 million)

- $\quad$ Abhishek Upmanyu (1.4 million)

- $\quad$ Abish Mathew (873K)

- $\quad$ Kanan Gill (699K)

- Kunal Kamra (929K)
- $\quad$ Biswa Kalyan Rath (553K)

- $\quad$ Sundeep Sharma (439K)

- Karunesh Talwar (426K)

- $\quad$ Sorabh Pant (294K)

- $\quad$ Aditi Mittal (241K)

- $\quad$ Varun Grover (233K)

- Daniel Fernandes (179K)

- Vaibhav Sethia (166K)

- $\quad$ Anirban Dasgupta (135K)

Each video of these comedians, available across different social media platforms - namely Facebook and YouTube - and OTT platforms such as Amazon Prime Video and Netflix were studied in detail to see how caste is spoken about in them. This was done following a process of open coding. Some of the direct codes studied include mentions of caste as a category and incidents of caste-based violence. But caste does not always find mention in a direct fashion and hence the literature review informed me of certain indirect ways that caste could be spoken about. These include - family profession, surnames, and skin tone. These codes were included in the coding frame as implicit references to caste. The codes were then analysed for frequency (how many times they come up in one particular set). The codes were recorded manually along with the joke they were a part of as to not decontextualize the utterances. Each code was accompanied by a definition from the beginning which helped prevent confusion of what it meant in the later stages of the study. Additionally, I focused on the response from the audience in terms of the laughter that a particular joke received. These have been indicated wherever applicable.

Code-switching presents the problem of translation. And since most performers switch between English and Hindi frequently while delivering the punch line, the transcribing process also included a fair bit of translation. The precise use of language and choice of words is important to this study and thus the coding process also accommodated the variances in language, especially the use and frequency of abusive language and expletives. But this introduces a complexity: not every Hindi word has an English equivalent and therefore not all words can be directly translated into English. Therefore, the motive was to get to the closest possible meaning to the word. 
The codes and the information derived were then arranged into successive themes. Braun and Clarke argue that when conducting thematic analysis for latent codes, the development of themes is interpretative work and not just mere description (13). I followed a process of theoretical thematic analysis with an emphasis on how the codes relate to the theoretical understanding of the issue at hand (Braun and Clarke 13). By finding repeated themes across various performances, I attempted to arrive at a broader understanding of the larger problem at play.

\section{English Stand-Up Comedy in India and the Absence of Caste-Related Discussions}

As it so happens, only four comedians out of the selected 15 have mentioned or hinted at the question of caste in all of their performances. This goes on to prove that on the Internet too, despite its relative creative freedom, caste is treated as a topic best left untouched. Two of the comedians, Zakir Khan and Kenny Sebastian, make a passing reference to caste and caste-based reservations and promptly move on to other topics. Zakir Khan, in his hour-long special, "Haq se Single" (2017) on Amazon Prime Video elucidates how people after a break-up question themselves and says:

Jab tum poochte ho ki mere saath aisa kyun huwa, tab jawab mein woh baat kehte ho jo tum nahin chahte koi bhi duniya mein tumko kahein - woh tumko isliye chhor ke chali gayi kyunki tum kaale ho... woh tumko isliye chhor ke chali gayi kyunki tumhari caste chhoti hain... par main yeh kehna chahta hoon ki har rishtey ki ek umar hoti hain, jab woh umar khatam hoti hain, woh relationship bhi khatam ho jaata hain...

[When you ask yourself, why did this happen to me? Then your answers are those that you would not want anyone else to tell you - she left you because you are dark... she left you because you belong to a low caste... but I want to say that every relationship has an age, when you mature, that relationship ends].

Kenny Sebastian in in his Amazon special, "Don't be That Guy" (2017), sings a song towards the end. In between, he asks the audience if they would like it to be more indie and finally says, "[L]et's put in some alaap [in Indian classical singing, the prologue to a formal expression], because there is reservation here also".

The absence of any discussion on caste is problematic, to say the least. With comedy videos gaining popularity across media platforms, and potentially changing how people in the country think, a lack of discussion on caste jeopardizes efforts to build a more caste-cognizant public sphere. A lack of discussion on caste consolidates the urban, liberal notion: 'caste is dead'.

\section{Stand-Up Comedy and the Assumption of Post-Caste}

The post-caste assumption also finds expression in the way comedians choose to talk about the issue of discrimination. Abhishek Upmanyu's gig elucidates that amply. In his video on YouTube, titled, "Breakup, Respecting Elders \& Discrimination" (2017), the comedian talks about discrimination in the following manner:

Main ek football match dekh raha tha, aur usme ek announcement huwa, bauhat ajeeb type ka, banda kehta hain, 'Today is the Anti-Discrimination Day, any discrimination on the basis of caste, creed, colour or sex would not be appreciated'... matlab tum kar lo, tareefein nahin kar rahe hum, thik hain? Compliments toh mat hi expect karna. [Laughter] And I think India ek jagah hain jahaan discrimination ko lightly lete hain, right? 'cause we have much bigger problems than discrimination. Consider Mumbai Police, every day they are getting cases of murder, kids getting stabbed, and somebody getting robbed, aur tab koi bhaisaab aa rahe hain, discrimination ki complaint leke, 'Sir, meri complaint likhna, usne mujhe kaala bol diya' [The audience bursts out in laughter and Upmanyu makes a funny face] Police wale ko gussa aa jayega. 'Dekh bhai, usne tujhe kaala bola kyunki tu kaala hain. Kaale, kaluye, bhaag yahan se. Abbey andhera hoga, kuch dikhega nahin, gaadi maar jayega tujhe.'

[I was watching a football match and there was an announcement, of a very weird kind - a man says, 'Today is Anti-Discrimination Day, any discrimination on the basis of caste, creed, colour or sex would not be appreciated'. This means you can do it, but do not expect any compliments.

[Laughter] India is one place where discrimination is taken lightly. This is because, there are much bigger problems. Consider Mumbai Police, every day, they get cases of murder, kids getting stabbed and somebody getting robbed and then there comes a man with a complaint of discrimination, 'Sir, write my complaint - that person called me dark'. [The audience burst out in laughter and Upmanyu makes a funny face] Even the police get angry and says that 'he has called you dark because you are. Now, you dark person, run. Very soon it will be dark and then no one will be able to see you, you might come under a car']. 
Upmanyu conveys the idea that there are several issues more important than discrimination in the country. This monologue is an example of the way in which mainstream media has treated the issue of caste-based discrimination by normalizing and trivializing it. This video demonstrates that the domain of English stand-up comedy is no different.

Equally problematic is the scourge of wrong information. Sundeep Sharma in a 6-minute video titled "Bombay ka Brahman Bro" (2017), analyses the famous controversy of Salman Khan (a popular Bollywood actor) killing a Blackbuck — an endangered, protected species. Seeing how Khan's lawyer managed to get him acquitted in the case [This video was produced in 2017. In 2018, Khan was convicted and then granted bail], he concludes that Khan must have had a Brahmin as a lawyer:

Yeh convincing powers sirf Brahmins ki hi ho sakti hain. Brahmins in the house give me a cheer [the audience makes noise and claps]. Sabse zyada convincing powers humari hoti hain [pointing to himself]. Kyunki humne saare samaj ko samjhaya, tumhare ghar main koi paida ho, toh hume khilao, koi mar jaaye, toh bhi hume khilao... aur humne jaati byavastha banai. Aur jab yeh banai humne, toh sabse upar kaun rahega? Hum. Humne kya kahaan? [Uses the mic stand to explain the divisions] Dekho, yeh sabse upar Brahmin, uske neeche Vaishya,

Baniya, uske neeche Kshatriya, uske neeche Shudra... hum [Brahmin] kya karenge? Hum tumhe batayenge ki tum kya karoge. Uske baad aayi Mayawati [inverts the stand]. Agli baar unhone sarkar banai toh usme sab Brahmin bhar rahe the, purpose fail... But humare paas zyada paise nahin hota hain. Cinema mein hero ka naam hota hain Raj Singhania, Vicky Malhotra, tum kabhi nahin sunoge ke Ferrari mein se koi hero nikle aur kahein 'Hi! I am Santosh Pandey'. Never happens. Bank-o mein zero balance account, humare liye khula tha... But hum log achchhe hote hain, duniya hum e samajh leti hain galat.

[This kind of convincing power can belong only to Brahmins. Brahmins in the house give me a cheer [the audience makes noise and claps]. We have the most convincing power [pointing to himself]. This is because we have convinced the society that if anybody is born in your community, feed us, if anyone dies, feed us... We have made the caste system. And who will remain at the very top? Us. And what will we do? [Uses the mic stand to explain the divisions] At the top will be Brahmins, right below them will be the Vaishyas or Baniyas, below them will be the Kshatriyas, below them the
Shudras. We, Brahmins, will tell everyone what to do. After this came Mayawati [inverts the mic to indicate that this political leader has changed the way caste is seen in politics]... We, Brahmins, do not have much money power. You will see that heroes in Hindi films usually have names like Raj Singhania, Vicky Malhotra. You will never hear a hero, getting out of a Ferrari, and introducing himself as 'Hi! I am Santosh Pandey' [Pandey being Brahmin surname]. This will never happen [pause for laughter]... We are good people, it is just that the world misunderstands us.]

Even though Sharma manages to depict the four strata in which castes are mostly grouped, it is factually incorrect. This is indicative of the lack of awareness where caste identities are concerned. This signals a deeper problem of the caste strata not being recognized enough in the modern public discourse. This post-caste attitude thus aids in circulation of the wrong ideas and contributes to the misinformation around caste. Sohail and Hasan conjecture that so common is the lack of information surrounding caste that sometimes caste identities are interchanged with regional stereotypes. Jokes do not spend time in etching out the differences between Haryanvis (people living in the northern state of Haryana) and Jaats (a caste group found in Haryana) (Sohail and Hasan).

\section{The Use of Disparaging Humour}

Comedy comes armed with power. The role of the comedians then becomes ever more critical in their function of power, resistance, and voicing truth to power (Kay 38). Standing on the stage, the comedian is in a superior position, a position to influence perceptions. However, not always positively. Humour and comedy can easily descend into ridicule and mockery and can be used to reinforce ideas of superiority. John Morreall understands this as the Superiority theory of humour. He describes it as deriving the essence of laughter from feeling superior to someone (121). Upmanyu's video on discrimination makes this clear. His use of disparaging words such as "kaale, kaluye" (literally translated as 'dark', abrasive words used to refer to people with dark skin tone), encourage their usage. In a country obsessed with a fair skin tone, calling a person dark is considered derisive for it fails to take into cognizance the association skin tone has with caste prejudice. If the raucous laughter that is heard in the background is any indication, Upmanyu is quite successful at reinforcing this prejudice. The comments section below this video on YouTube did not have a single negative feedback, rather people lauding him for his wit and 'keen observations'. This disparagement humour silences the marginalized, but more important, creates an acceptability of these prejudicial attitudes. 
Upmanyu, in his position of power, gives out the message that in this context, one need not consider discrimination seriously or critically thereby encouraging his viewers to suspend all notions about it too.

\section{The Absence of the Dalit Voice}

Stand-up comedy employs autobiographical performance directed towards dissemination of a broader message. It allows the artiste to perform both self and culture and it is the juxtaposition of the two that becomes important in the acceptance of the joke. The very fact that Sharma constantly pointed at himself whenever he spoke of Brahmins as a group, reveals that society is yet not comfortable joking about caste identity objectively. The teller can only hope to evoke a (positive) response if he belongs to that group. His jokes were funny because he was self-deprecating.

Sanjay Rajoura, a political satirist, criticizes the Indian stand-up scene by saying that it does not touch upon the soul of the country - caste politics. This, he says, is largely because the comedians belong to elite classes (Sahoo 245). A cursory glance at the caste identities of Indian comedians (an exhaustive list is available on indianstandups.com) reveals that an overwhelming majority are upper caste males. The rest are upper-caste females. This demonstrates that Indian comedy, in spite of its democratizing potential, is still in the grips of the upper-caste elites. Unsurprisingly then, issues pertaining to lower castes are hardly discussed. It should be safe to assume that jokes about Dalits and the oppression they face will be possible only once a Dalit comedian is empowered enough to take the stage by breaking through the ranks that is so closely guarded by upper caste men. This absence of Dalit comedians from the comedy scene, however, has to be located amidst the broader socio-historical structure. Inaccessibility to English education and lack of exposure to the Internet are some of the many reasons why the comedy space still eludes the Dalit comedian. Former comedian Gursimran Khamba is of the opinion "I do see stand up continuing to be a force of resistance but I also see it only being that simply because the government is not going to give it that much importance. If we were Dalit stand-up comics going from village to village talking against the Brahmins, we would have been shot or killed or been under arrest... Let's be honest, we are upper middle-class people with cultural capital” (Khamba).

The concern of punching up/down cannot be left behind when discussing caste in comedy. Making a joke at the expense of a group less powerful is constantly a problem in a sphere that is completely dominated by upper-caste males. Self-deprecating humour can only be possible if the comedy space is made accessible to the Dalit voice. But a larger question of acceptability is at play here - how much will the English educated middle-class, most of whom belong to the upper-castes, with its post-caste assumption be comfortable with hearing a Dalit person on stage making fun of the historical oppression they have had to face, fully aware that they too are complicit in their suffering?

\section{Conclusion}

A topic becomes funny only after enough time has passed. The taboo of caste still lurks too close to the skin, comes loaded with years of guilt and recrimination. The comedy scene in India has been successful at bringing up uncomfortable topics for discussion, but as this study demonstrates, it has still not been able to break the silence around caste. Here it treads the path adopted by the traditional media, one replete with absence, misinformation and disparagement of caste considerations and adopts the attitude that 'caste is not important'. It continues to pander to the middle-class demand for clean, elite comedy. This cannot be expected to change very soon. There is time till Dalit comedians make their presence felt on mainstream comedy, perform their marginality, and challenge the power structure in the process. The comedy space needs to be liberated from the clutches of the upper-caste, upper-class men if the question of caste is to be discussed. For this, the potential of the Internet stand-up comedy to alter the public sphere needs to be realized more fully. Then only can a cultural turn based on humour be achieved (Sahoo 246).

This study is by no means intended to be an exhaustive account of the current state of comedy in the country. Neither does it claim to give a complete picture of the multiple facets of caste discrimination. Instead, it argues that even though comedy studies have not relegated much importance to the study of caste, humour's historical association with discrimination and empowerment can be successfully appropriated in the Indian context. In so doing, it lays the groundwork for more analysis on this subject.

\section{References}

Akbar, Prayag. "Caste lives on, and on: Indian society deludes itself that caste discrimination is a thing of the past, yet it suffuses the nation, top to bottom." Aeon, 20 April 2017,

https://aeon.co/essays/how-india-deludes-itself-that-castediscrimination-is-dead. Accessed 23 April 2019.

Ambedkar, Bhimrao Ramji. "Castes in India: Their mechanism, genesis and development." Readings in Indian Government and Politics Class, Caste, Gender, 2004, pp. 131-53.

Berreman, Gerald. D. "Caste in India and the United States." American Journal of Sociology, vol. 66, no. 2, 1960, pp. 120127. 
Braun, Virginia, and Victoria Clarke. "Using thematic analysis in psychology." Qualitative Research in Psychology, vol. 3, no. 2, 2006, pp. 77-101.

Caliandro, Alessandro. "Digital methods for ethnography: Analytical concepts for ethnographers exploring social media environments." Journal of Contemporary Ethnography, vol. 47, no. 5, 2018, pp. 551-578.

Chadha, Monica, and Summer Harlow. "The writing is on the wall, or is it? Exploring Indian activists' beliefs about online social media's potential for social change." International Journal of Communication, vol. 9, no. 5, 2015, pp. 672-693.

Das, Preeti. "Dalit boy stabbed for sporting moustache; third attack in a week in Gujarat village". The Indian Express, 04 Oct. 2017. https://indianexpress.com/article/india/dalit-teen-stabbed-forsporting-moustache-third-attack-in-a-week-in-gujarat-village4873228/ Accessed 22 April 2020.

Davies, Christie. Jokes and targets. Indiana University Press, 2011.

Desai, Sonalde, and Veena Kulkarni. "Changing educational inequalities in India in the context of affirmative action." Demography, vol. 45, no. 2, 2008, pp. 245-270.

Dhillon, Amrit. "How social media is empowering India's Dalits." The Globe and Mail, 25 July 2016,

https://www.theglobeandmail.com/opinion/how-social-mediais-empowering-indias-dalits/article31091710/. Accessed 22 April 2020.

Don't Be That Guy. Kenny Sebastian, Stage 42 Productions, OML, Amazon Prime Video, 2017.

https://www.primevideo.com/region/eu/detail/0R1B9NL93I9T H1XCT9W9YZQ06V/ref=atv_sr_def_c_unkc_1_1_1?sr=11\&pageTypeIdSource=ASIN\&pageTypeId=B071CZ2C21\&qid $=1599771993$

Elst, Koenraad. "Humour in Hinduism". Humour and Religion: Challenges and Ambiguities, edited by Hans Geybels, Walter Van Herck, London: Bloomsbury Academic, 2011, 35-53.

Farooq, Omer. "Rohith Vemula: The student who died for Dalit rights.” BBC News, 19 Jan. 2016,

https://www.bbc.com/news/world-asia-india-35349790. Accessed 30 April 2019.

Fernandes, Daniel. “Marital Rape.” YouTube, 25 May 2015,

https://www.youtube.com/watch?v=n9Cq14qMrQ8\&t=308s. Accessed 23 July 2020

Gerow, Edwin. "Why the Fish Laughed, and Other Matters Relating to (the Indian Sense of)" Humor." Studia Orientalia Electronica 94, 2001, pp. 167-180.

Gettleman, Jeffrey and Raj, Suhasini. "Tell Everyone We Scalped You!' How Caste Still Rules in India.” The New York Times, 17 Nov., 2018,

https://www.nytimes.com/2018/11/17/world/asia/tell-everyone-wescalped-you-how-caste-still-rules-in-india.html. Accessed 22 April 2020

Geybels, Hans, and Walter Van Herck, eds. Humour and religion: Challenges and ambiguities. Bloomsbury Publishing, 2011.

Gopalakrishnan, R. "For a few laughs more."Fountainink, 2 April 2015, https://fountainink.in/reportage/for-a-few-laughs-more. Accessed 30 March 2020?

Gould, Harold A. "The adaptive functions of caste in contemporary Indian society." Asian Survey, vol. 3, no. 9, 1963, pp. 427-438.

Gupta, Dipankar. "Caste and politics: Identity over system." Annu. Rev. Anthropol, vol. 34, no.21, 2005, pp. 409-427.
Grover, Varun. "Notebandi par Varun Grover ki stand-up comedy."YouTube, uploaded by The Lallantop, 2016, https://www.youtube.com/watch?v=gseji9BCsSE\&t=212s. Accessed 23 July 2020 ?

Haq se Single. Zakir Khan, Stage 42 Productions, OML, Amazon Prime Video, 2017.

https://www.primevideo.com/region/eu/detail/0J7ZN4B9J2AG BRNET2R5GOVFAI/ref=atv_sr_def_c_unkc_1_1_1?sr=11\&pageTypeIdSource=ASIN\&pageTypeId=B073QDFN34\&qid $=1599772922$

Jaffrelot, Christophe. "Sanskritization vs. ethnicization in India: Changing identities and caste politics before Mandal." Asian Survey, vol. 40, no. 5, 2000, pp. 756-766.

Joshi, Ruchir. "No humour please, we are Indian." The Hindu, 16 July 2017, https://www.thehindu.com/opinion/columns/nohumour-please-we-are-indian/article19286300.ece. Accessed 30 April 2019.

Kay, Kavyta. New Indian Nuttahs, Palgrave Macmillan, Cham, 2018.

Khanduri, Ritu G. "Vernacular punches: Cartoons and politics in colonial India." History and Anthropology, vol. 20, no. 4, 2009, pp. 459-486.

Kumar, Sangeet. "Transgressing boundaries as the hybrid global: Parody and postcoloniality on Indian television." Popular Communication, vol. 10, no. 1-2, 2012, pp. 80-93.

Kumar, Suresh C. "Indian Mass media's approach towards Dalits in India.” Indian Journal of Research, vol. 5, no. 7, 2016, pp. 6667.

Kumar, Suresh C. and Subramani, R. "Internet as an alternative media for Dalits in India: Prospects and challenges." IOSR Journal of Humanities and Social Science, vol. 19, no. 2, 2014, pp. 125-129.

Lakshmi, R. "India's booming stand-up comedy scene tests boundaries with cutting-edge jokes." The Washington Post, 21 Aug. 2014,

https://www.washingtonpost.com/world/asia_pacific/indiasbooming-stand-up-comedy-scene-tests-boundaries-with-cuttingedge-jokes/2014/08/20/a4e6a4db-90b5-4700-aa11f371cb40c9d1_story.html?utm_term=.44783ffc712 d. Accessed 17 June 2020 ?

MacDonald, James Lorien. "Comic trans: presenting and representing the other in stand-up comedy", Live art and Performance studies, Uniarts Helsinki, 2018.

Mintz, Lawrence E. "Standup comedy as social and cultural mediation." American Quarterly, vol. 37, no.1, 1985, pp. 71-80.

Mittal, Aditi. "Sanitary Napkins| Things they wouldn't let me say." YouTube, 4 March 2016, https://www.youtube.com/watch?v=bIapVfDTgBY. Accessed 23 July 2020 ?

Morreall, John. "Humor, philosophy and education." Educational Philosophy and Theory, vol. 46, no. 2, 2014, pp. 120-131.

Mosse, David. "Outside Caste? The Enclosure of Caste and Claims to Castelessness in India and the United Kingdom." Comparative Studies in Society and History, vol. 62, no.1, 2020, pp. 4-34.

Nagarajan, K. "A largely Upper-caste Media is Not Good for India's Democracy.” The Wire, 9 Sept. 2015, https://hewire.in/media/a-largely-upper-caste-media-is-notgood-for-indias-democracy. Accessed 23 April 2020? 
Naim, C. M. "Popular Jokes and Political History: The Case of Akbar, Birbal and Mulla Do-Piyaza." Economic and Political Weekly, 1995, pp. 1456-1464.

Nüske, Lea Sophie. Comedy as Resistance: Indian Stand-Up Comedians and Their Fight Against India's Anti-Democratic Tendencies. 2018. Universität Potsdam, Master's Thesis. https://www.unipotsdam.de/fileadmin/projects/wci/Masterarbeit_Indian_StandUpComedy_4485_.pdf.

Paul, Subin. "A new public sphere? English-language stand-up comedy in India." Contemporary South Asia, vol. 25, no. 2, 2017, pp. 121-135.

R, Smitha. "Violence against Dalits see a 35\% surge since 2014 in Gujarat." DNA, 16 May 2019,

https://www.dnaindia.com/ahmedabad/report-violence-againstdalits-see-a-35-surge-since-2014-in-gujarat-2749689. Accessed 22 Feb. 2020.

Rani, Jeya. "The Dalit Voice is Simply Not Heard in the Mainstream Indian Media." The Wire, 15 Nov. 2016, https://thewire.in/media/caste-bias-mainstream-media. Accessed 19 Feb. 2019?.

Ray, Tinku. "The US isn't safe from the trauma of caste bias." WGBH News, 08 March 2019, https://www.pri.org/stories/201903-08/us-isn-t-safe-trauma-caste-bias. Accessed 20 April 2019.

Ross, Alison. The language of humour. Routledge, 2005.

Sahoo, Sonali, and Rolla Das. "Is English Stand-Up Comedy in India Intersectional?” Language in India, vol. 18, no. 9, 2018, pp.240-249.

Sebastian, Kenny. "Why I Don't Do Jokes About Politics in India." Youtube, 22 April 2018,

https://www.youtube.com/watch?v=azFe8b6yfb0\&t=344s. Accessed 23 Feb. 2019?

Sharma, Arvind. "Dr. BR Ambedkar on the Aryan invasion and the emergence of the caste system in India." Journal of the American Academy of Religion, vol. 73, no. 3, 2005, pp. 843870.

Sharma, Sundeep. "Bombay ka Brahman, Bro." YouTube, 5 May 2017, https://www.youtube.com/watch?v=2K7tw3IWi6s\&t=2s. Accessed 18 Feb. 2019?

Siegel, Lee. Laughing matters: Comic tradition in India. The University of Chicago Press, 1989.

Singh, Harsha. "Comedian Kunal Kamra asked to move out of his house due to "political issues." The Times of India, 25 Jan. 2018, https://timesofindia.indiatimes.com/viral-news/comediankunal-kamra-asked-to-move-out-of-his-house-due-to-politicalissues/articleshow/62647201.cms. Accessed 22 Feb. 2020.

Sohail, Jagat and Nomaan Hasan. Humourous Worlds: A Study of Stand-Up Comedy in the Delhi-NCR Region, Department of Sociology, Delhi School of Economics.

Starks, Helene, and Susan Brown Trinidad. "Choose your method: A comparison of phenomenology, discourse analysis, and grounded theory." Qualitative Health Research, vol. 17 no. 10, 2007, pp. 1372-1380.

"Tanmay Bhat || Varun Grover || Vir Das - I AM OFFENDED". BeingIndian, YouTube, 4 Feb. 2015, https://www.youtube.com/watch?v=swozBbWMzNQ\&t=1070s

Thakur, Arvind Kumar. "New Media and the Dalit Counter-Public Sphere." Television \& New Media, vol. 21, no. 4, 2020, pp. 360375.
Thomas, Paul. Humour, Wit, and Satire from Indian Classics. Ernakulam: Joseph Thomasons, 1969.

Upmanyu, Abhishek. "Breakup, Respecting elders \& discrimination." YouTube, 13 March 2017, https://www.youtube.com/watch?v=8q4xY8NO7yQ\&t=2s. Accessed 6 Feb. 2019.

Vasudevan, Lokpria. " 2 arrested for forcing Dalit man to eat human faeces in Tamil Nadu." India Today, 08 May 2019, https://www.indiatoday.in/crime/story/dalit-attacked-15201542019-05-08. Accessed 22 April 2020.

Weaver, Simon. "A rhetorical discourse analysis of online antiMuslim and anti-Semitic jokes." Ethnic and Racial Studies, vol. 36, no. 3, 2013, pp. 483-499.

Yadav, Vijay Kumar. "Mumbai Police arrests Nalasopara resident for giving rape threat to comedian Joshua." Hindustan Times, 13 July 2020, https://www.hindustantimes.com/indianews/mumbai-police-arrests-nalasopara-resident-for-givingrape-threat-to-comedian-joshua/storyJL17 orwJqKhNf3WTFlu0wK.html. Accessed 20 July 2020.

Waghmore, Suryakant. "Challenging Normalised Exclusion: Humour and Hopeful Rationality in Dalit Politics." From the Margins to the Mainstream: Institutionalising Minorities in South Asia, edited by Hugo Gorringe, Roger Jeffery, Suryakant Waghmore, Sage, 2016, 153-177. 